\title{
1924 Yılından Günümüze Ordu-Ünye Çömlekçiliği
}

\section{Ordu-Ünye Pottery from 1924 to The Present}

\section{Filiz Öztürk}

Dr. Öğr. Üyesi, Ardahan Üniversitesi Güzel Sanatlar Fakültesi Resim Bölümü

email: zfilizozturk@gmail.com (DORCID ID: https://orcid.org/0000-0001-6317-1833



Atıf (APA 6)/To cite this article

Öztürk, F. (2020). 1924 y1lından günümüze Ordu-Ünye çömlekçiliği. Atatürk Üniversitesi Güzel Sanatlar Enstitüsü Dergisi, $26(44), 21-37$. doi: https://doi.org/10.35247/ataunigsed.670754

Makale Gönderim Tarihi/Received: 28/12/2019

Makale Kabul Tarihi/Accepted: 11/03/2020

Makale Yayın Tarihi/Published: 19/03/2020

Research Article / Araştırma Makalesi

Öz

Ordu-Ünye'de çömlekçilik yapan Rumların 1924 yılı TürkiyeYunanistan mübadelesi ile gitmeleri, çömlekçi atölyelerinin boș kalmasına neden olmuștur. Dönemin ileri gelen girişimcilerinden İlyasoğlu Ahmet Yıldız, atölyeleri işletmek için çömlekçilikten anlayanları arastırmıs ve 93 Harbi (1877-1878 Osmanlı-Rus Savaşı) sırasında Artvin-Borçka'dan Trabzon'un Of ilçesine göç etmis Ellibes ailesine ulaşmıștır. Bu ailenin, Borçka'da yaşayan diğer akrabaları, Ünye'ye yeni çırak ve ustalar yetiştirmesi için davet edilmiştir. Ünye çömlekçiliğinin canlandırılması girișimleri başarılı olmus ve atölyelerin ürettiği ürünlere talep artmıştır. Borçkalı çömlek ustaları,1927 sonrası yeni çırak ve ustalarını yetiștirmis ve uzunca bir süre Ünye çömlekçiliği üzerinde etkili olmuștur. Tüm bu çabalarla Ünye, 1927-1980 yılları arasında önemli bir çömlek üretim ve satış merkezi haline gelmistir. Ancak ucuz endüstriyel ürünlerin ortaya çıması ve kullanımının yaygınlaşması, çoğu el sanatının yok olmasına sebep olmustur. $\mathrm{Bu}$ sürecin ortaya çıardığ 1 ekonomik sürdürülebilirlik sorunu Ünye cömlekçiliğinin de sonunu getirmiştir. Uzunca bir süre Doğu Karadeniz bölgesi için önem arz eden Ünye çömlekçiliğinin incelenmesi için bir saha araştırması yapılmıştır. Çalışmada elde edilen bilgilerle, 1927 sonrası Borçkalı ustalar tarafindan yeniden sekillenen Ünye çömlekçiliği özelliklerinin araştırılması ve belgelenmesi amaçlanmıştır.

Anahtar Kelimeler: Ünye, Borçka, Burunucu, Çömlekçilik, Mübadele, Sahilköy, Şükrü Ellibeş

\begin{abstract}
The fact that Greeks who were potter in Ordu-Unye went with the exchange of the Turkey-Greece in 1924 caused potter's ateliers to become empty. İlyasoglu Ahmet Yildiz, who was one of the leading entrepreneurs of the period, researched those who had knowledge about pottery to run ateliers and he reached Ellibes family who emigrated from Artvin-Borcka to Of district of Trabzon during the 93 War (the years between 1877 and 1878 Ottoman-Russian War). Other relatives of this family living in Borcka were invited to Unye to train new apprentices and craftsmen. Attempts to revive Unye pottery succeeded and the demand for the products produced in the ateliers increased. The pottery craftsmen of Borcka trained new apprentices and craftsmen after 1927 and were effective on Unye pottery for a long time. With all these efforts, Unye became an important pottery production and sales center between the years 1927 and 1980. However, the emergence and widespread use of cheap industrial products caused the destruction of most handicrafts. The economic sustainability problem posed by this process also brought the end of Unye pottery. A field study was carried out to search the Unye pottery, which was important for the Eastern Black Sea region for a long time. With the information obtained in the study, it was aimed to research the characteristics of Unye pottery which was reshaped by the craftsmen of Borcka after 1927 to document
\end{abstract}

Keywords: Unye, Borcka, Burunucu, Pottery, Exchange, Sahilköy, Şükrü Ellibeş

\section{Giriş}

Eylül 2018'de Borçka çömlekçiliği hakkında araştırma yapmak üzere bir saha çalışması gerçekleştirilmiştir. 1940-1960 yılları arasında Ünye'den, Borçka'ya çalışmak üzere birçok çömlekçi ustasının geldiği öğrenilmiştir. Araştırma derinleştirildiğinde 1927-1935 yılları arasında Borçka'dan da çömlekçi ustalarının Ünye’ye gittiği bilgisine ulaşılmıştır. Her iki yöre çömlekçilerinin yer değișikliğinin sebepleri araştırıldığında ise Borçkalı ustaların 1927-1935 yılları arasında Ünye'ye gelişinin, 1924 yılında Türkiye ile Yunanistan arasında gerçekleşen mübadele ile ilişkili olduğu öğrenilmiştir. $\mathrm{Bu}$ tarihlerde mübadele ile Ünye'den gidenler arasında Rum çömlekçiler de vardır. Cumhuriyet'in ilk yıllarına denk gelen bu süreçte birçok alanda kalkınma ve ilerleme çabalarına girișildiği bilinmektedir. Bu çabalar çerçevesinde Ünye'de, Rum çömlekçilerin geride bıraktığ1 atölyelerin işletilmesi için çeşitli düşünceler geliştirilir. 1927'de dönemin ileri gelen girişimcilerinden İlyasoğlu Ahmet Yıldız bu amaca yönelik çalışmalara başlar ve öncelikle yörede çömlekçi ustası arayışına girer. Yörede bulunan usta ve çırak sayısı atölyeleri işletmeye yeterli değildir. Bu arayışta 93 Harbi (1877-1878 Osmanlı-Rus Savaşı) zamanında Artvin-Borçka'dan Trabzon'un Of ilçesine göç eden "Ellibeşler" diye bilinen aileye ulaşılır. Bu aileden çömlekçi Şükrü Usta, çırak ve usta yetiştirmesi için Ünye'ye davet edilir. Eğitimlere yoğun talep olması nedeniyle Şükrü Usta, Borçka'dan çömlek ustası olan kardeşi Hasan Ellibeş’i çağırır, usta ve çırak eğitimine birlikte devam ederler. O dönemlerde bu eğitimleri veren ustalara çok yüksek maaşlar ödenir ve ustalar çok önemsenir [A. D. Varilci (kişisel iletişim, Nisan-Kasım 2019); A. Kabayel (kişisel iletişim, Nisan-Kasım 2019)]. İlyasoğlu Ahmet Bey'in yanında çalışan Şükrü Usta, zamanla kendi işletmesini açar ve Borçka'dan 
akrabalarını getirterek, birlikte çömlek üretmeye devam eder. İlyasoğlu Ahmet Bey ise atölyesini devam ettirmek için Adil Dilek ve Haydar Dilek ustalar ile anlaşır.

Ünye çömlekçiliğinin yeniden canlanması sürecini daha iyi anlamak için Şükrü Ellibeş ve Hasan Ellibeş’in yakınlarına ulaşılmıştır. Hasan Usta'nın oğlu Yusuf Ellibeş ile görüşülmüş, kendisinden Ünye'de doğduğu ve 1952 yılında 12 yaşına geldiğinde ise ailece Borçka’ya geri döndükleri bilgisi alınmıştır [Y. Ellibeş (kişisel iletişim, Kasım 2019)]. O sıralarda Şükrü Usta, Ünye Belediye Başkanı olmuş, bu süreçte atölyesini işletmeye devam etmiştir. Borçka'ya dönen Hasan Usta çömlekçiliği bırakmış ve çömlek yapımına oğlu Yusuf Usta başlamıştır. Hasan Usta ve Yusuf Usta, Borçka'da sarma ile biçimlendirmede kullanılan ayak çarkı ile az sayıda ürün üretilmesi sebebiyle Ünye'de öğrendikleri çarkın aynısını Borçka'da yapar ve kullanırlar. Bu sebeple 19401960 yılları arasında Ünye'den Borçka'ya ustalar gelir ve çalışır, ancak Borçka'nın suyu sevmeyen çamur yapısı nedeniyle yörenin kendine has çarkı daha çok kullanılmaya devam edilir (Öztürk, 2018, s. 989)

Şükrü Usta'nın oğlu Aydın Ellibeş ile yapılan görüşmede, ortaokul dönemlerinde hemen hemen herkesin çömlekçilik yaptığını, atölyelerin siparişlere yetişemediği bilgisi alınmıştır. Yöredeki çoğu genç gibi kendisi de okuldan sonra ve yaz aylarında babasının atölyesinde çamur hazırlama ve topaç yapma gibi işlerde çalıştığını ve harçlık aldığını belirmiştir [A. Ellibeş (kişisel iletişim, Kasım 2019)].

\section{Yöntem}

Kaynak incelemesi ve aynı zamanda saha araştırmasında derinlemesine görüşmeler yapılmıştır. 1927-1980 yılları arasında, ailesinde çömlekçilik yapan kişilere ulaşılmış ve kişisel görüşmeler yapılmıştır. Nitel araştırma yöntemleri çerçevesinde ulaşılan bilgilerin kaynaklarına erişilerek elde edilen bulgular kayıt altına alınmıştır.

\section{3. Ünye Çömlekçiliği}

\subsection{Atölyeler ve Ustalar}

Ünye'de Rumlardan sadece üç adet firın kaldığı, diğer firınların ve atölyelerin 1927 yılından sonra yapıldığı bilgisine ulaşılmıştır [A. D. Varilci (kişisel iletişim, Nisan-Kasım 2019; Y. Ellibeş (kişisel iletişim, Kasım 2019)]. Geçmişte Burunucu Çömlekçi Mahallesi’nde 19 ila 24 kadar çömlekçi atölyesinden söz edilirken, Güngör Güner, 1972-1977 yılları arasını kapsayan “Anadolu’da Yaşamakta Olan İlkel Çömlekçilik” isimli kitabında, Ünye'de altı çömlekçi atölyesi bulunduğunu bildirmiştir. Yine aynı eserde biçimlendirmede kullanılan çarkların tamamının elektrikle çalıştığı bilgisini de vermiştir (Güner, 1988, s. 91)

Ünye'de büyük çömlekçi atölyelerine fabrika denilmiş ve bu fabrikalarda üç ya da dört çömlekçi birlikte seri üretim yapmıştır. Salih Usta'nın belirttiğine göre 1960'lı yıllarda gelen siparişlere yetişmekte sıkıntı çekilmiştir. Bu dönemlerde Ünye'de çömlekçi atölyelerinde çalışanların sayısının 300 kişinin üzerinde olduğu ve çömlek üretimi dışındaki işlerde kadınların da çalıştığı öğrenilmiştir [S. Karayiğit (kişisel iletişim, Ekim 2019); Y. Ellibeş (kişisel iletişim, Kasım 2019)]



Görsel 1. Burunucu mahallesi

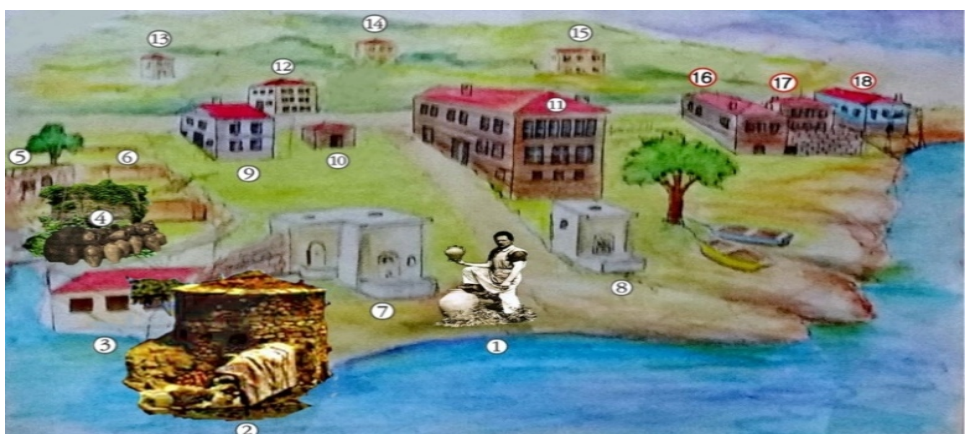

Görsel 2. Burunucu mahallesi çömlekçi atölyeleri ve firınlar 1959 yılı öncesi 
Yörede 1927-1980 yılları arası çömlekçilik yapan ustaların isimleri şöyledir: Ahmet Ellibeş, Şükrü Ellibeş, Hasan Ellibeş, Hüseyin Ellibeş, Espas Usta, Babucoğlu Ahmet, Bekir Çağlar, Hamza Çağlar, İbrahim Öztürk, Adil Dilek, Haydar Dilek, Hasan Çil, Ahmet Çil, Şükrü Şevket Yeğin, İbrahim Şen, Mahmut Şen, (Hanumcuk) Hasan Öztürk, Mustafa Öztürk, Emin Necati Güvenç, Hacı Hüseyin Adalı, İbrahim Adalı, Adnan Adalı, Edip Adal1, Batumlu Mehmet Efendi, Yakup Kaya, Mustafa Kaya, Afyonlu İbrahim Usta, Sivaslı Kara Mehmet, İbrahim Karayiğit, Nihat Mutlu, Bahri Çiçek, Bilal Kocatoros, Ahmet Kocatoros, Faruk Yıldız, Haluk Yıldız, Mahmut Tabak, Mehmet Tabak, Kemal Tabak, Hasan Hilmi Saka, İsmail Kök, Hüseyin Mistepe (Taşçı Hüseyin), Salih Karaosmanoğlu, Mehmet Kavaklı, Mevlüt Kabayel, İbrahim Şenalp, Şerafettin Denizci, Şükrü Denizci (Memiş Kaptan), Osman Karayiğit, Salih Karayiğit [A. Kabayel (kişisel iletişim, Nisan-Kasım 2019); A. D. Varilci (kişisel iletişim, Nisan-Kasım 2019); M. U. Mistepe (kişisel iletişim, Kasım 2019); S. Karayiğit (kişisel iletişim, Ekim 2019)].



Görsel 3. Burunucu sahili’nde 1950’li yıllarda çömlekçi çamuru hazırlama işlemi

Tablo 1

Ufuk Mistepe ve Hüseyin Mistepe’nin hazırladığı çömlekçi fırınları listesi (“Çanak çömlek”, 2019)

\begin{tabular}{|c|c|}
\hline \multicolumn{2}{|c|}{$\begin{array}{l}\text { ONNYE'DE CCÖMLEK FIRINLARI (FABRIKALARI) } \\
\text { Kaynak: Cōmlekci Başustası Hüseyin MiSTEPE } \\
\text { (1920-1980 arası) }\end{array}$} \\
\hline 1) Rumlar'ın Çömlek İmalâthaneleri & $\begin{array}{l}\text { Nufus Mũdürü Galip Keşaph'nun Orta Mah., } \\
\text { Keşaphı Sokak'taki evlerinin karşısındaki } \\
\text { bahçede.. } 2 \text { adet. }\end{array}$ \\
\hline 2) Rumlar'ın Çömlek İmalâthanesi & $\begin{array}{l}\text { Lâmbabiciler'in Makinist Osman'm Evlerinin } \\
\text { Yanunda } 1 \text { Çōmlek Frrm. }\end{array}$ \\
\hline 3) ilyasoğlu Ahmet'in Imalâthanesi & $\begin{array}{l}\text { Ünye - Samsun Karayolu üzerinde, sol üstte } \\
\text { ve Berber Enver'in evinin } 3 \text { ev çarşı } \\
\text { istikametinde } 2 \text { adet Çömlek Furun ve } 1 \text { adet } \\
\text { Atölye. }\end{array}$ \\
\hline $\begin{array}{l}\text { 4) Adil / Haydar - Rasiye Dilek'in } \\
\text { Imalâthanesi }\end{array}$ & $\begin{array}{l}\text { Orta Mahalle ile Burunucu Mahallesi } \\
\text { arasında Dereboğaz Mevkii'nde } 1 \text { Atölye ve } 1 \\
\text { Furm. }\end{array}$ \\
\hline $\begin{array}{l}\text { 5) Lâzzâde Ruşen Efendi'nin } \\
\text { Imalâthanesi }\end{array}$ & Köprübaşı mevkiindedir. \\
\hline 6) Ahmet Kavaklıoğlu'nun İmalâthanesí & Köprübaşı mevkiindedir. \\
\hline 7) Adil - Haydar Dilek'in Ímalâthanesi & Hanboğazı - Yasemin Eczanesi'ne varmadan. \\
\hline 8) Afyonlu íbrahim Usta'nun İmalâthanesi & $\begin{array}{l}\text { Hanboğazı - Yasemin Eczanesi'nin az } \\
\text { ilerisinde. }\end{array}$ \\
\hline $\begin{array}{l}\text { 9) Daşçı İsin Usta (Hüseyin MisTEPE) } \\
\text { Iml. }\end{array}$ & Ortaokul arkası, Dereağzı mevkii (3 adet). \\
\hline 10) ilyasoğlu Ahmet'in İmalâthanesi & $\begin{array}{l}\text { Çömlekçi Mahallesi, Dereağzı mevkii, deniz } \\
\text { kenar. }\end{array}$ \\
\hline
\end{tabular}


Tablo 1'in devamı

\begin{tabular}{|c|c|}
\hline 11) Bekir - Hamza'nun İmalâthanesi & Burunucu Mahallesi, Tilla Çayevi mevkii. \\
\hline 12) Piş̧irik İbrahim'in İmalâthanesi & Burunucu Mahallesi, Tillâ Çayevi mevkii. \\
\hline 13) Faruk - Haluk Yıldız'in Imalâthanesi & Burunucu Mahallesi, Tillâ Çayevi karşısı. \\
\hline 14) Mevlüt Kabayel'in İmalâthanesi & Burunucu Mahallesi, Tillâ Çayevi bitişiği. \\
\hline 15) Borçkalı Şükrū Ellibeş'in İmalâthanesi & $\begin{array}{l}\text { Burunucu Mahallesi, } 55 \text { Apt. karşısı, deniz } \\
\text { kenar. }\end{array}$ \\
\hline $\begin{array}{l}\text { 16) Hanımcik Hasan Öztürk'ün } \\
\text { İmalâthanesi }\end{array}$ & Burunucu Mahallesi, Mağaza Önü mevkii. \\
\hline 17) Haca İbrahim Adalı'nun İmalâthanesi & Burunucu Mahallesi, Maḡaza Önü mevkii. \\
\hline 18) Hamdi Usta'nun imalâthanesi & Burunucu Mahallesi, Mağaza Önü mevkii. \\
\hline 19) Necati Usta'nun Imalâthanesi & Burunucu Mahallesi, Mağaza Önü mevkii. \\
\hline 20) Pabuçoḡlu Ahmet'in İmalâthanesi & $\begin{array}{l}\text { Burunucu Mahallesi, Atatürk ilkokulu } \\
\text { arkası. }\end{array}$ \\
\hline 21) Borçkalı Şükrū Ellibeş'in İmalâthanesi & Burunucu Mahallesi, Çamlık karşısı. \\
\hline $\begin{array}{l}\text { 22) ismail - ibrahim Kök'lerin } \\
\text { İmalâthanesi }\end{array}$ & Burunucu Mahallesi, Çamlık karşısı. \\
\hline 23) Adil - Haydar Dilek'in İmalâthanesi & Burunucu Mahallesi Mezarlık mevkii. \\
\hline 24) Borçkalı Șükrū Ellibeş'in İmalâthanesi & Aynikola mevkii. \\
\hline
\end{tabular}

Tablo 2

Ufuk Mistepe ve Salih Karayiğit’in verdiği bilgilere göre oluşturulan yıllara göre atölyeler ve ustaları

\begin{tabular}{|c|c|c|}
\hline Atölye & Usta ve Çıraklar & Form/Üretim Biçimleri \\
\hline $\begin{array}{l}\text { İlyasoğlu Ahmet } \\
\text { Y1ldız atölyesi } \\
\text { 1927-1985 }\end{array}$ & $\begin{array}{l}\text { Bekir Çağlar } \\
\text { Espas Usta } \\
\text { Ahmet Ellibeş } \\
\text { Şükrü Ellibeş } \\
\text { Trabzonlu Haydar Dilek ve Adil } \\
\text { Dilek } \\
\text { Ahmet Ellibeş } \\
\text { Şükrü Ellibeş } \\
\text { Hüseyin Mistepe } \\
\text { Faruk Yıldız } \\
\text { İbrahim Adalı } \\
\text { Haluk Yıldız } \\
\text { Mehmet Yıldız } \\
\text { Hasan Öztürk } \\
\text { Şükrü Yeğin } \\
\text { Mehmet Tabak }\end{array}$ & $\begin{array}{l}\text { Ahmet Yıldız'ın atölyesinde geleneksel formlar üretilmiştir. Biçimlendirmede } \\
\text { ayak çarkı ile birlikte Şükrü Ellibeş; Borçka'da kullanılan çark tipini de } \\
\text { Ünye'de kullanmıştır. Borçka'ya has küp ve güveç gibi formlar üretilmiştir. } \\
\text { İçleri ziftle (sakızlı küp) kaplanmış büyük turşu küpleri yapılmıştır. } \\
\text { Espas Usta, yeni formlar üretmiştir; lazımlık, öveç (testi), düdük, pöğrek (boru), } \\
\text { saksı, biblo vs. } \\
\text { Espas Usta'nın sır uygulamayı bildiğini ancak diğer çömlekçilere öğretmediği } \\
\text { bilgisi Salih Karayiğit'ten alınmıştır. } \\
\text { Ellibeşlerin atölyesinde 1952-1960 yılları arasında Marsilya kiremidi } \\
\text { üretilmiştir. Kiremit makinası Avrupa'dan getirtilmiştir. Manika insan gücü ile } \\
\text { çalıştırılmıştır. }\end{array}$ \\
\hline $\begin{array}{l}\text { Şükrü Ellibeş Atölyesi } \\
\text { 1930-1958 }\end{array}$ & $\begin{array}{l}\text { Şükrü Ellibeş } \\
\text { Hasan Ellibeş } \\
\text { Hüseyin Ellibeş } \\
\text { İbrahim Karayiğit } \\
\text { Espas Usta } \\
\text { Hüseyin Mistepe } \\
\text { Faruk Yıldız } \\
\text { Haydar Dilek } \\
\text { Adil Dilek } \\
\text { Bekir Çağlar } \\
\text { İbrahim Adalı } \\
\text { Hasan Ellibeş } \\
\text { Haluk Yıldız } \\
\text { Mustafa Öztürk } \\
\text { Hasan Öztürk } \\
\text { Şükrü Yeğin }\end{array}$ & $\begin{array}{l}\text { Geleneksel formlar üretilmiştir. İlk motorlu çamur çekme makinasını kullanan } \\
\text { atölyedir. Biçimlendirmede ayak çarkı ile birlikte Borçka'ya has çark } \\
\text { kullanılmıştır. } \\
\text { İbrahim Karayiğit, Şükrü Ellibeş’in atölyesinde çalıştığı dönemde geleneksel } \\
\text { formları üretilmesinin yanında kalıp ile biçimlendirme de yapılmıştır (1944yılı } \\
\text { itibari ile). İbrahim Usta kalıp ile şekillendirme ve sırlama işlemlerini Afyon ve } \\
\text { Kütahya'daki seramik atölyelerde öğrenmiştir. Fincan, çaydanlık gibi formlar } \\
\text { üretmiştir. Sırlamada sülyen, soda ve boraks ilaveli bulamaç kullanılmıştır. } \\
\text { Astarlı ürünler de üretilmiştir. } \\
\text { Ağırlıklı olarak büyük ebatlı çömlek imalâtı yapılmıştır. Özellikle içleri ziftle } \\
\text { (sakızlı küp) kaplanmış büyük turşu küpleri üretilmiştir. } \\
\text { Saksı, vazo, pöğrek (boru), ibrik, baca borusu gibi küçük ebatlı ürünler az } \\
\text { miktarda yapılmıştır. }\end{array}$ \\
\hline
\end{tabular}


Tablo 2'nin devamı

\begin{tabular}{ll}
\hline Atölye & Usta ve Çiraklar \\
\hline & Bekir Çağlar \\
& Zeki Ergün \\
Bekir Çağlar Atölyesi & Hüseyin Mistepe \\
$1931-1959$ &
\end{tabular}

\section{Form/Üretim Biçimleri}

Bekir Usta, çömlekçiliği Bulgar Espas Usta'dan öğrenmiştir. Fırını, Selanik göçmeni Hürmüsa Hanım'dan satın almıştır. Biçimlendirmede ayak çarkı kullanılmışıtır. Bekir Usta'nın atölyesinde geleneksel astarlı ve sırlı formlar üretilmiştir. Sırlamada sülyen, soda ve boraks ilaveli bulamaç kullanılmıştır. Büyük ve küçük ebatlı çömlek üretimi yapılmıştır.

Zeki Ergün, Bekir Usta'nın atölyesinde pöğrek kalıbında boru kesme işleminde çalışmıştır. Hüseyin Mistepe'de kısa bir süre Bekir Usta'nın yanında çalışmıştır. Geleneksel formlar üretilmiștir. Biçimlendirmede ayak çarkı kullanılmıștır. Sırlı ürünler genellikle İbrahim Usta tarafından yapılmıştır. Sırlamada sülyen, soda ve boraks ilaveli bulamaç kullanılmıştır. İçleri ziftle (sakızlı küp) kaplanmış büyük turşu küpleri yapılmıştır.

Tahsin Usta $\quad$ Tahsin Usta (Rüşanların Tahsin) Tahsin Usta, 1955-1967 İtalya'dan delikli tuğla makinası getirtmiştir. Tuğla İbrahim Karayiğit makinası, Ünye'de liman olmadığı için açıkta demir atan gemiden çapar teknesi ile Ünye sahiline indirilmiştir. Makine elektriksizdir ve 2-3 iş̧̧i kuvveti ile çalıstırılmıştır. 6-8 delikli tuğla üretimi yapılmıştır. Tahsin Usta'nın atölyesi, delikli tuğla, takoz tuğla, çömlek üretimi ve kireç üretiminin yapıldığı dört bölümden oluşturulmuştur.

\begin{tabular}{|c|c|c|}
\hline $\begin{array}{l}\text { Adil Dilek } \\
\text { Haydar Dilek Rasiye } \\
\text { Dilek Atölyesi } \\
1930 \text { - } 1975\end{array}$ & $\begin{array}{l}\text { Adil Dilek } \\
\text { Haydar Dilek } \\
\text { Hüseyin Mistepe } \\
\text { Mehmet Tabak } \\
\text { Celal Karadayı }\end{array}$ & $\begin{array}{l}\text { Geleneksel astarlı ve sırlı formlar üretilmiştir. Biçimlendirmede ayak çarkı } \\
\text { kullanılmıştır. Sırlamada sülyen, soda ve boraks ilaveli bulamaç kullanılmıştır. } \\
\text { Büyük ebatlı çömlek imalâtı yapılmıştır. } \\
\text { İçleri ziftle (sakızlı küp) kaplanmış büyük turşu küpleri yapılmıştır. }\end{array}$ \\
\hline $\begin{array}{l}\text { Faruk Yilmaz } \\
\text { Atölyesi } \\
1955-1975\end{array}$ & $\begin{array}{l}\text { Faruk Yıldız } \\
\text { Hamdi Kaya } \\
\text { İbrahim Karayiğit }\end{array}$ & $\begin{array}{l}\text { Geleneksel formlar üretilmiştir. Biçimlendirmede ayak çarkı kullanılmıştır. } \\
\text { İçleri ziftle (sakızlı küp) kaplanmış büyük turşu küpleri yapılmıştır. } \\
\text { İbrahim Karayiğit, Faruk Yıldız’ı atölyesinde çalıştığı dönemde ürün sırlama } \\
\text { ile ustalaşmıştır. Sırlamada sülyen, soda ve boraks ilaveli bulamaç } \\
\text { kullanılmıştır. Sırlı reçel ve bal kavanozları üretilmiştir. Salih Karayiğit, en iyi } \\
\text { sırlamanın Faruk Yıldız atölyesinde yapıldığı bilgisini vermiştir. }\end{array}$ \\
\hline
\end{tabular}

Hüseyin Usta, biçimlendirmede ayak çarkı kullanmıştır. Espas ve Şükrü Usta'nın yanında yetişmiştir. Çapulacılık, Marangozluk, Taşçılık, Çömlekçilik yapmıştır. Hemen hemen tüm ustalarla birlikte çalışmış ve yeni nesil çırakların

Hüseyin Mİstepe (Taşçı Hüseyin) Atölyesi birçoğuna ustalık etmiştir. Hüseyin Usta geleneksel form üretimi yanı sıra kendi Hüseyin Mistepe tasarımlarını yaparak, üretmistir. Alçı kalıp ile biçimlendirme ve seramik yüzeyler için üzüm ve çiçek kabartmaları yapmıştır. Döküm kili olarak geleneksel Ünye çömlekçiliğinde kullanılan toprağı ve dışarıdan getirttiği daha açık renkli toprağı döküm çamuru olarak hazırlamıştır. Alçı kalıba çamur basma yöntemi ile de üretim yapmışıır.

Cömleklerin pişiriminde, evinin bahçesinde kendi yaptığı üc çömlek firınını kullanmıştır. Kü̧̈ük ebatlı sırlı ve astarlı çömlek üretimi yapmıştır. Hüseyin usta atölyesinde deneysel çalışmıştır.

Atölyesini kurmadan önce babası İbrahim Karabulut ve Tahsin ustanın yanında çalışmıştır.

1970'de motorlu çark, sadece Mahmut Sen ve Salih usta tarafindan

Salih Karayiğit 1970-Hala devam

Salih Karayiğit ediyor kullanılmıştır.

Salih Usta atölyesinde tuğla ve kiremit dışındaki bütün sırlı-sırsız geleneksel formları üretmiştir. Günümüzde atölyesinde az da olsa sipariş üzerine ürün yapmaktadır. Salih Usta, valilik ve belediyenin organizasyonlarında çömlekçi çarkında çömlek yaparak geleneksel çömlekçiliğin tanıtımına katkıda bulunmaktadir.

\section{2.Ünye Çömlekçiliğinin Özellikleri}

\subsubsection{Hammadde Temini ve Camur Hazırlama}

Atölyelerde üretim Mart-Kasım ayları arasında gerçekleştirilmiş, kış aylarında üretim yapılmamıştır. Günümüzde ise Salih Usta, atölyesini 12 ay açık tutmaktadır. Seri bir şekilde çömlek üretimi yapmadığından hazırladığı çamurun tüm yıl boyunca yeterli geldiğini belirtmiştir.

Çömlek yapımında kullanılan "cilim ya da celim" denilen toprak, önceleri Burunucu Mahallesi Çamlık Mevkii'nden getirilirken günümüzde Atatürk Mahallesi'nde bulunan Laz Selahattin'in findıklığından ya da civarından getirilmektedir. Çamur hazırlama işlemine üretim sezonundan yaklaşık bir ay kadar önce başlanır. Çömlek yapımına uygun toprak, yüzeyin $15-20 \mathrm{~cm}$ kadar kazılmasından sonra elde edilir. Uygun toprak, Salih Usta tarafından, "killi, kaymak gibi temiz ve pürüzsüz olmalı" şeklinde tarif edilmiştir. Çamur hazırlama alanına getirilen toprak, önce tokmakla ufalanır ve su ile karıştırılır. Toprağın sslatılarak bekletildiği havuza "yalak" (Görsel 4) denilir. Çamurun yalakta bekletilmesinin önemi, çömlekçiler tarafindan kullanılan "çamur yalakta pişer" deyimiyle açıklanabilir. Çömlekçiliğin aktif yapıldığı dönemlerde toprak elenmeden sslatılır, içindeki taş ve yabancı maddeler kadınlar tarafından ayıklanırken, Salih Usta günümüzde toprağı eleyerek kullanmaktadır. 
Bekleme süresince çamur yığını nemini kaybetmesin diye ara ara sulanır ve çürümeye bırakılır. Çamur önceden ayakla ezilirken (Görsel 5) sonraları elektrikli çamur ezme makineleri kullanılmıştır. Günümüzde ise vakumpresten (Görsel 6) geçirilir ve topaçlar (künde) halinde çarkta biçimlendirilmeye hazır hale getirilir.



Görsel 4. Salih Usta-Çamur hazırlama

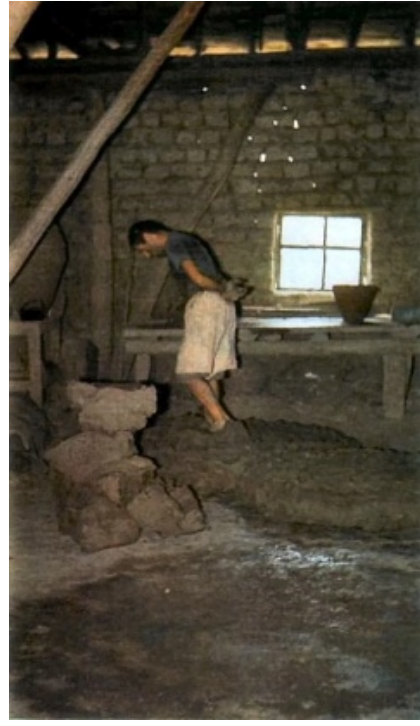

Görsel 5. 1950-1960 çamur hazırlama işlemi

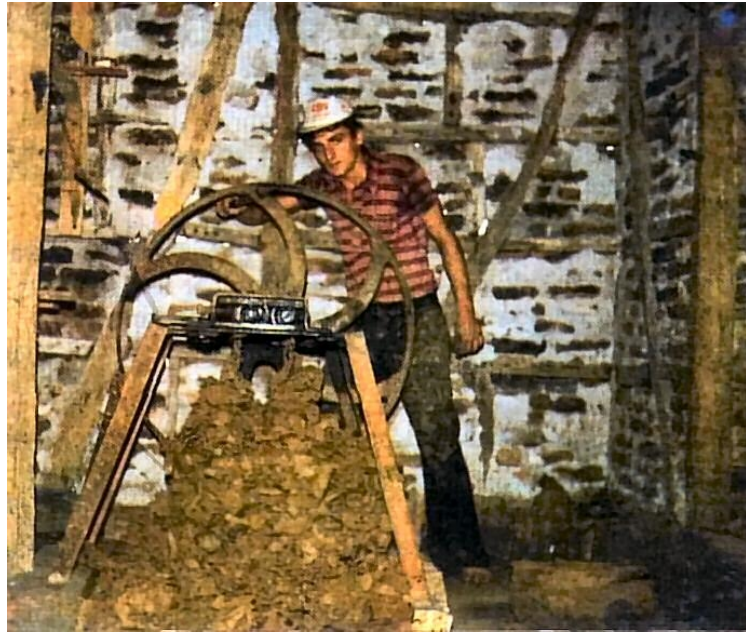

Görsel 6. Çamurun presten geçirilmesi

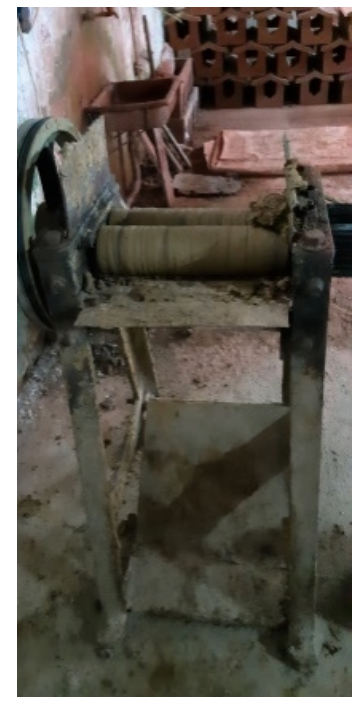

Görsel 7. Salih Karayiğit atölyesi

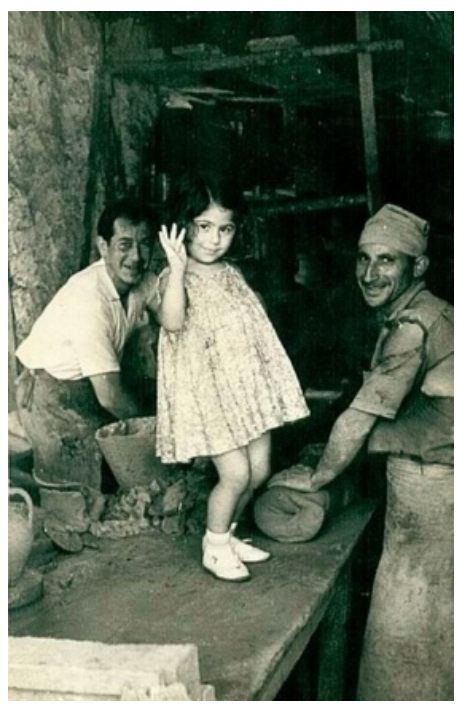

Görsel 8. Çömlek ustaları Abdullah Güney ve Faruk Yıldız 


\subsubsection{Biçimlendirme}

Çamur biçimlendirmede, elektrikli çarklar ortaya çıkana kadar ayakla döndürülen çarklar kullanılmıştır. Salih Usta'nın atölyesinde hem ayakla döndürülen hem de elektrikli çark bulunmaktadır. Usta, atölye üretimlerini elektrikli çark (Görsel 11) ile yaparken festival ve etkinliklerde tanıtım amaçlı ayakla döndürülen çarkı (Görsel 10) kullanmaktadır. Çarkların tezgahları kapalıdır ve çark oturağına tezgâh üzerine çıkılarak geçilmektedir. Geçmişte üretim için kullanılan çarklara, fabrika tipi çark denilir. Bu tür tezgâhın kullanımının, seri şekilde üretilen ürünlerin konulacağı alanın geniş tutulma ihtiyacından kaynaklandığı belirtilmiştir [S. Karayiğit (kişisel iletişim, Ekim 2019)].

Geçmişte yörede ayakla döndürülen çarkla birlikte, Şükrü Usta aracılığı ile Borçka'nın kendine has ayakla döndürülen çarkı da (Görsel 9) kullanılmıştır. Borçkalı ustalar, yöre çömlekçiliği üzerinde etkili olduğu sürece her iki çarkın da kullanımının devam ettiği bilgisine ulaşılmıştır [Y. Ellibeş (kişisel iletişim, Kasım 2019)]. Salih Usta, 1950'li yıllara kadar Hasan Ellibeş’in sarma yöntemini kullanarak büyük küpler yaptığını, babasının gördüğünü ancak kendisinin Hasan Usta dönemine yetişemediği bilgisini vermiştir. Ünye’de ve Borçka'da üretilen büyük küpler "cadı küpü” ya da "cazı küpü” olarak isimlendirilir (“cadı” ya da "cadi” aynı zamanda mısır unu için de kullanılır). Üretim şekilleri ve süreleri aynıdır. Bu küplerin yapıldığı çark tipinin Ünye’de de kullanıldığı bilgisi Ahmet Derya Varilci, Yusuf Ellibeş ve Salih Usta tarafından teyit edilmiştir.

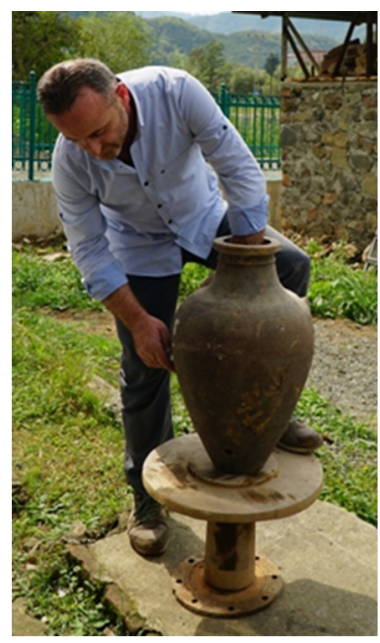

Görsel 9. Borçka'da kullanılan çark

Cadı küpleri büyüklüklerine göre üç parça halinde biçimlendirilir. Boyutlarına göre değişen ölçülerdeki dip kısımları, çarkta 20-30 cm kadar yükseldikten sonra bir gün bekletilip bu süre içinde ek yapılacak kısımları kurumaması için incir yaprağı ile sarılır ya da "malez" (balçık) sürülerek kuruması engellenir. İkinci gün üçte ikisi bitecek şekilde yükseltilir ve aynı işlemler uygulanır. Üçüncü gün son parça eklenerek biçimlendirme işlemi tamamlanır. Çömleklere ayrıca bir rötuş işlemi uygulanmaz. Kulp ve ağızlık gibi ekler biçimlendirmeden bir gün sonra dayanıklılık kazandığında eklenir. Daha önce takılması durumunda ek yapılan yerin deforme olması ya da eklenen parçanın düşmesi gibi sorunlarla karşılaşılması söz konusudur.

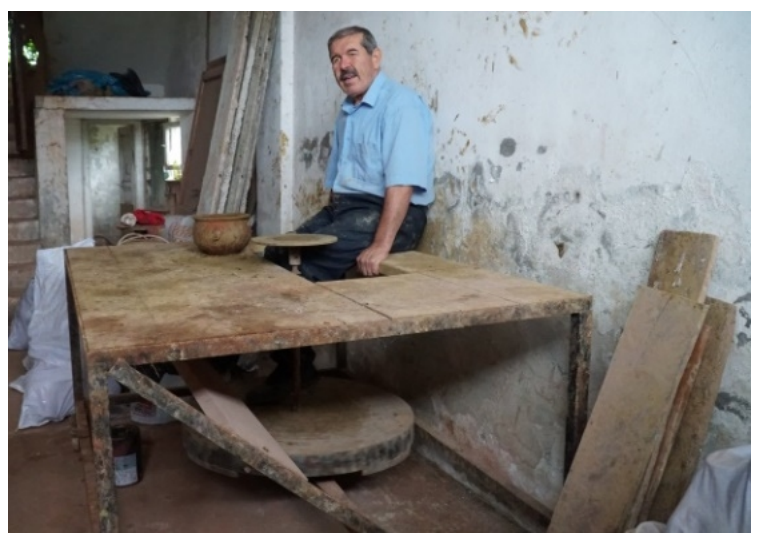

Görsel 10. Ayakla döndürülen çark, Ünye 




Görsel 11. Ünye’de kullanılan elektrikli çark ve seri üretimlerde kullanılan kapalı tezgah,

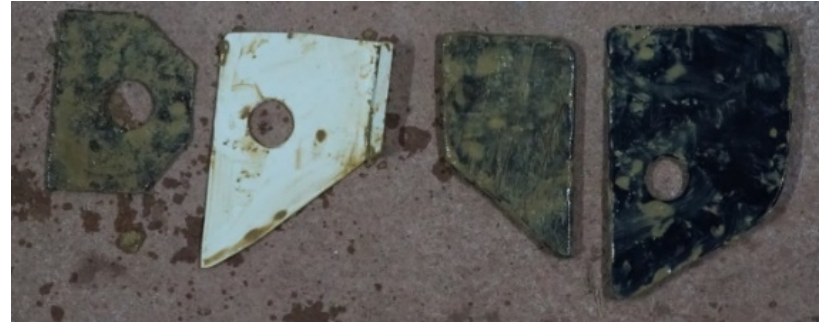

Görsel 12. Biçimlendirmede kullanılan plastik ve metal aletler

1944 yılında Afyon'dan Ünye'ye gelen İbrahim Karayiğit, Afyon ve Kütahya'da seramik fabrikalarında çalışmıştır. Bu nedenle alçı kalıpla seramik üretmeyi ve sırlamayı bilmektedir. Çalıştığı atölyelerde alçı kalıp ile çaydanlık ve fincan gibi formlar üretmiştir. Hüseyin Mistepe, İbrahim ustadan alçıdan model, kalıp yapmayı ve form üretmeyi öğrenmiş, sonrasında ise daha da geliştirmiştir. Ancak Ünye çömlekçiliğinde alçı kalıp ile form üretimi yaygın ve yoğun bir biçimde yapılmamıştır. Alçı kalıplarda, geleneksel Ünye çamuru ve civar bölgeden getirilen açık renkli toprak kullanılmıştır. Salih Usta tarafından alçı kalıplarda kullanılan çamurların yapısı, iyice süzülmüş, işlenmiş bulamaç şeklinde tarif edilmiştir.

\subsection{3. Üretilen Formlar}

Ünye'deki çömlekçi atölyelerinde üretilen formlar, günlük kullanım ev araç-gereçleri (yiyecek-içecek kabı, saksı vb.) ve yapı malzemeleri olarak iki gruba ayrılabilir. Her iki gruptaki ürünler 1927-1980 yılları arasında geleneksel yöntemlerle üretilmiştir. Üretim yoğunluğu nedeniyle büyük atölyeler fabrika gibi çalışmış ve üretim yapmiştır.

Yiyecek içecek için kullanılan ürünlerin en büyük özelliği su sızdırmaz olmasıdır. Salih Usta, su sızdıran çömlekçi çamurunu tanımlarken "lı̆̆ toprak" deyimini kullanmıştır. Ünye'nin çömlekçi çamurunun ise "lı̆̆" olmadığını belirtmiştir. Yörede günlük kullanım için üretilen formlar; yayık, testi, çeşitli boylarda güveç, çeşitli boylarda küp, vazo, saksı, kumbara, ibrik, mangal, sibek (lazımlık), düdük, kül yalağı, tabak, delikli keş kabı gibi malzemelerdir. Ayrıca Borçka'da şarap ve tahıl saklamak için yapılmış 18 kg'lık 17 adet tenekeyi alabilen büyük küpler yapılmıştır. Borçka' da bu küpler sıvı doluyken insan düşerse ölebileceği düşüncesi yaygındır ve bu nedenle "cadı küpü ya da cazı küpü” olarak isimlendirilmiştir.

Yöre çömlekçiliğinde en az miktarda yiyecek alan kapların başına çocuk ismi getirilmiş, en fazla miktarda yiyecek alan kaplar için de 18 kiloluk teneke (bir teneke alana birli küp denilir) sayısına göre isim verilmiştir. Bu ölçü Borçka’daki küpler içinde kullanılmaktadır. Küpler, "birli küp”, “ikili küp”, “üçlü küp”, "dörtlü küp”, "beşli küp" ve daha büyükleri de "cadı küpü” ya da "cazı küpü” şeklinde isim almıştır. İki saplı küpler, "küçük lima küpü” (2 teneke alır) ve "büyük lima küpü” (3 teneke alır) olarak isimlendirilmiştir. İbrik ölçüleri, "çocuk ibrik”, "on beşlik ibrik", "yarımlık ibrik" şeklinde belirtilmiştir. Çömlekler (güveç) ise "çocuk çömlek", "on beşlik çömlek", “yarımlık çömlek" şeklindedir. Üç boy üretilen çömleklerin dip kısımları dar yapılır (Görsel 13) ve ateşe oturtulur. Ünye çömlekleri su sızdırmaz özellikte olduğu için ilk pişirimden önce yağlanmaya ihtiyaç duymazlar ancak çömlekler ateşe içi yiyecek ve su doldurularak konulmalıdır, aksi takdirde patlayabilmektedir. Ayrıca "yarımlık su testisi", "büyük su testisi”, "hanıştıra su testisi”" (en az iki teneke su alır) (Görsel 16-17), yandan tek saplı 1,5 teneke bal alan bal küpü, "testi öveci” (turşu kabı), "ağzı geniş testi öveci” (ayran kabı) gibi kullanım alanına göre formlar da üretilmiştir. Turşu testileri su sızdırmaması için ziftleme işlemine tabi tutulmuştur. Turşu küpleri bisküvi pişirimi yapıldıktan sonra ateşte belli bir sıcaklığa kadar kızdırılır ve içine iki kepçe kaynar zift dökülerek çalkalanır, agız kısmına kadar zifte bulaştırılır. Bu işlem küpün su sızdırmasını önler. Ziftli küplere "sakızlı küp” denilir.

Yap1 malzemesi olarak, tuğla, kiremit, pöğrek (temiz ve pis su borusu) (Görsel 19), baca tepeliği, soba borusu, boru dirseği, nefeslik (sigara içilen yerlerde içerideki havayı temizlemek için bacaya takılır) (Görsel 20) gibi 
formlar üretilmiştir. Tuğla ve kiremit üretimi hem yörenin kendi ihtiyacı hem de civar illerin ihtiyacını karşılamıştır. Çömlek yapımında kullanılan çamur ile tuğla ve kiremit yapımında kullanılan çamur farklıdır. Çömlek yapımında daha plastik çamur kullanılmıştır.



Görsel 13. İlyasoğlu Ahmet Yıldız 1925-1935 Ünye’de üretilen formlar



Görsel 14. 1972-1977 yılları arası Ünye'de üretilen formlar

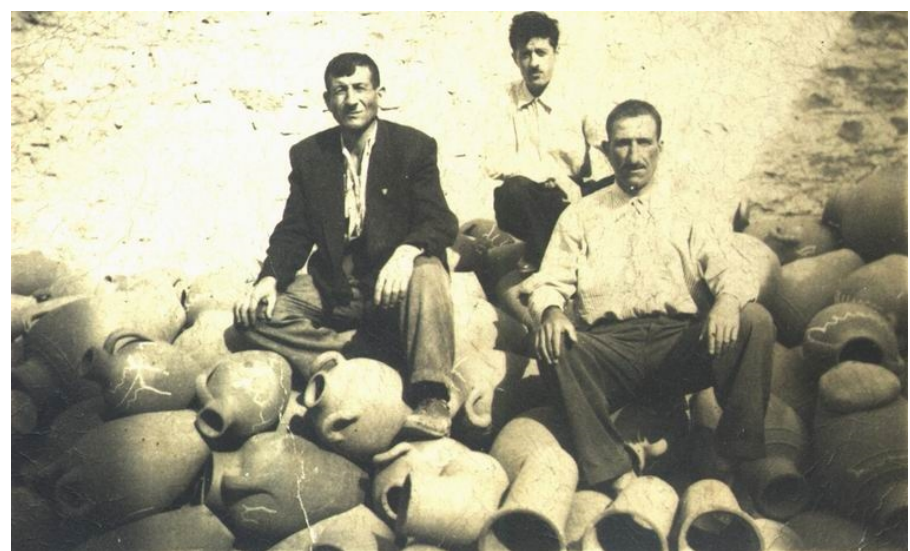

Görsel 15. Ünye’nin çömlekçi ustaları 




Görsel 16. Çömlekçi çırağının omuzundaki üçlü küp, sağdaki çömlekler hanıştıra su testisi



Görsel 17. 1- Abdest testisi, 2- Birli küp, 3- Hanıştıra su testisi

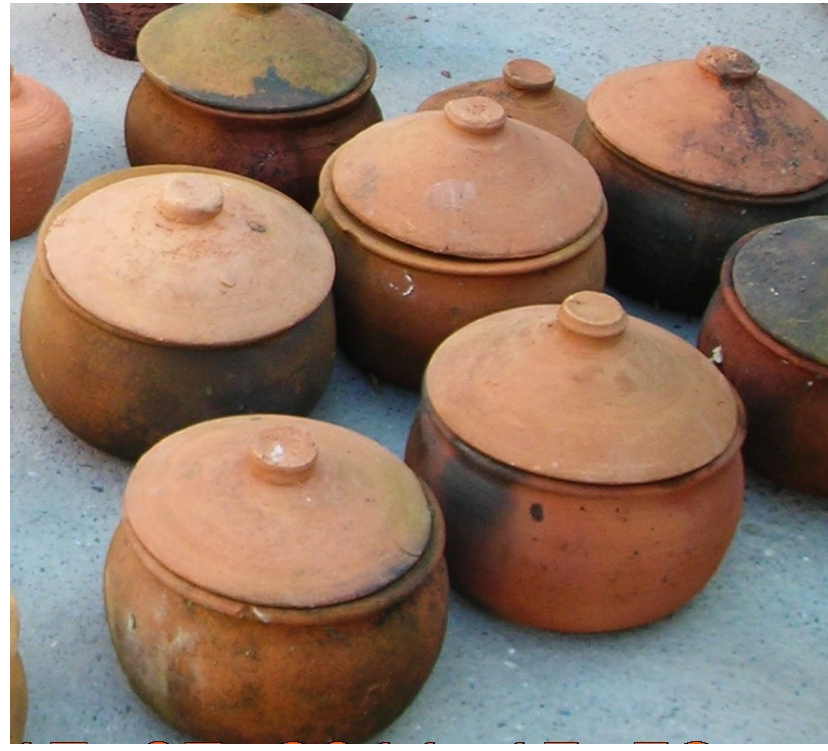

Görsel 18. Yakın zamanda (2011) Ünye'de yapılan güveçler 


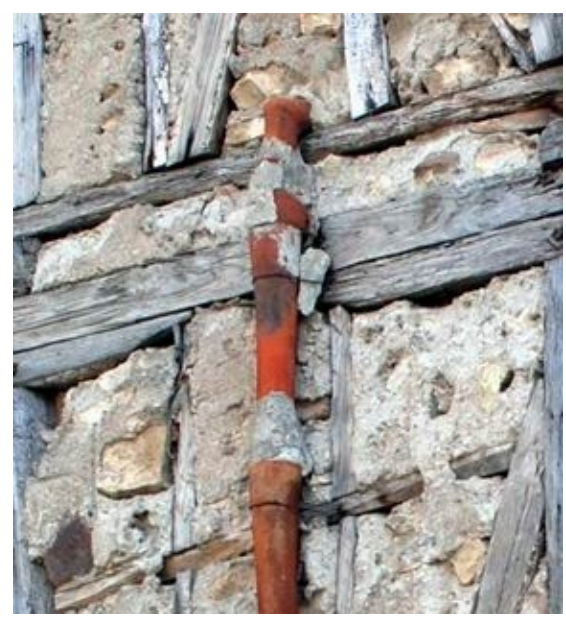

Görsel 19. Pöğrek (boru)

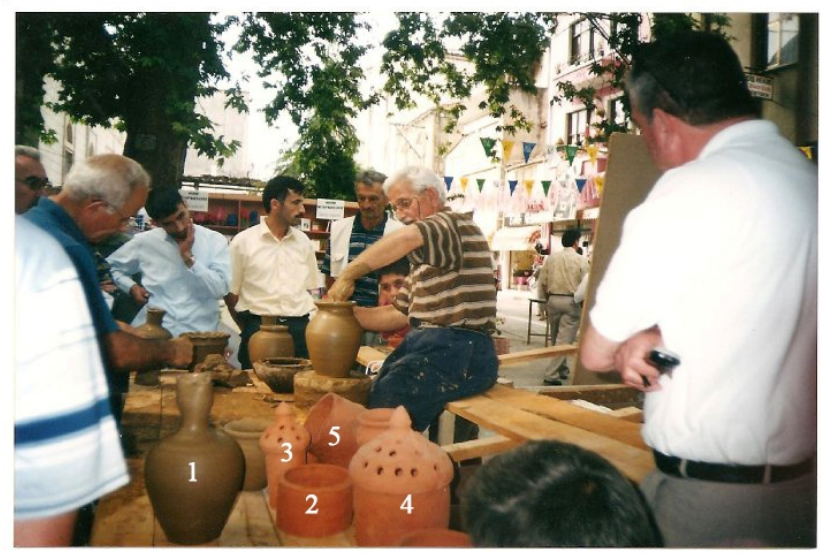

Görsel 20. İbrahim Adalı Usta, 1- Sürahi, 2- Künk, 3 ve 4- Küçük-büyük baca havalandırma kapağı (nefeslik), 5- Boru dirseği
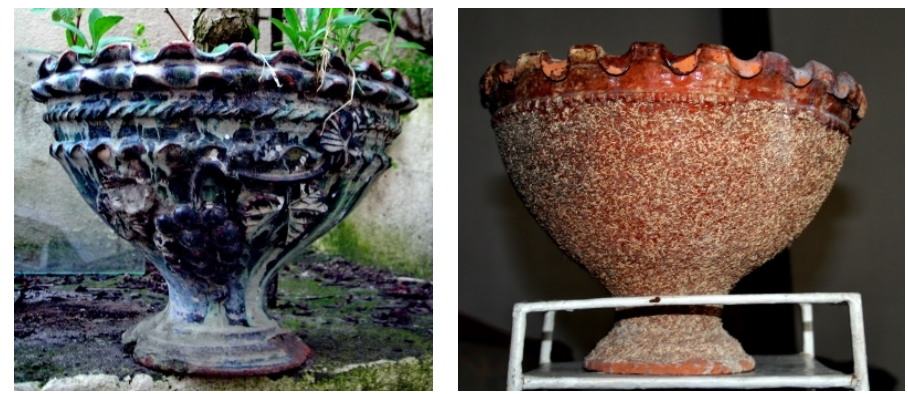

Görsel 21. Ünye'de üretilen sırlı formlar

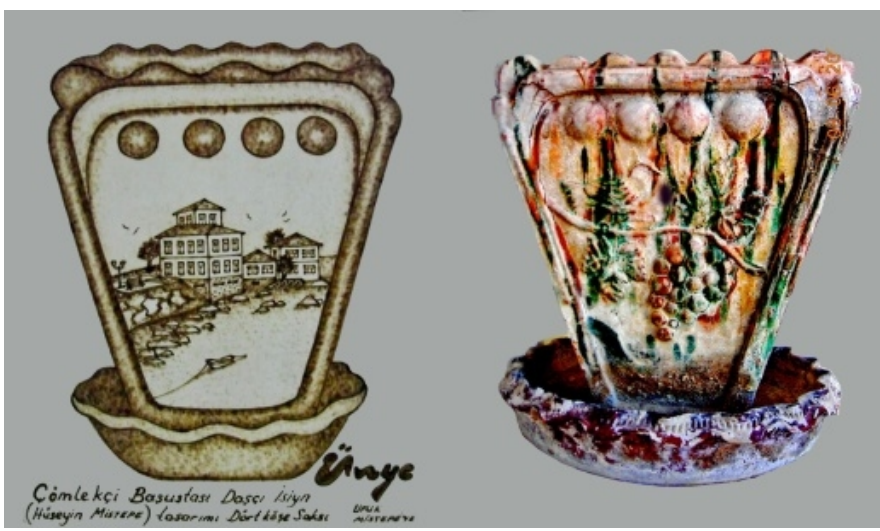

Görsel 22. Hüseyin Mistepe Usta’nın tasarladığı saksı 


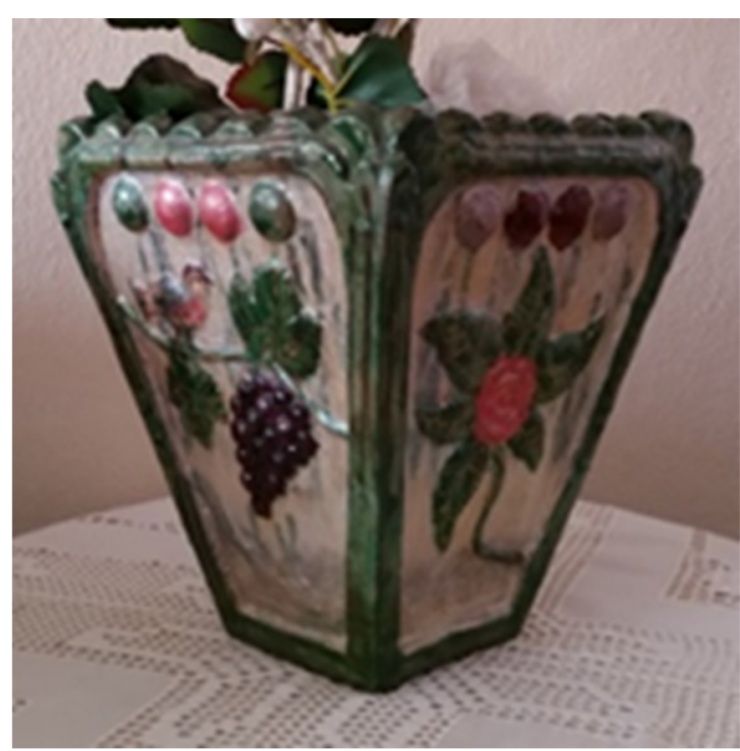

Görsel 23. Hüseyin Mistepe ürettiği sırlı saksı

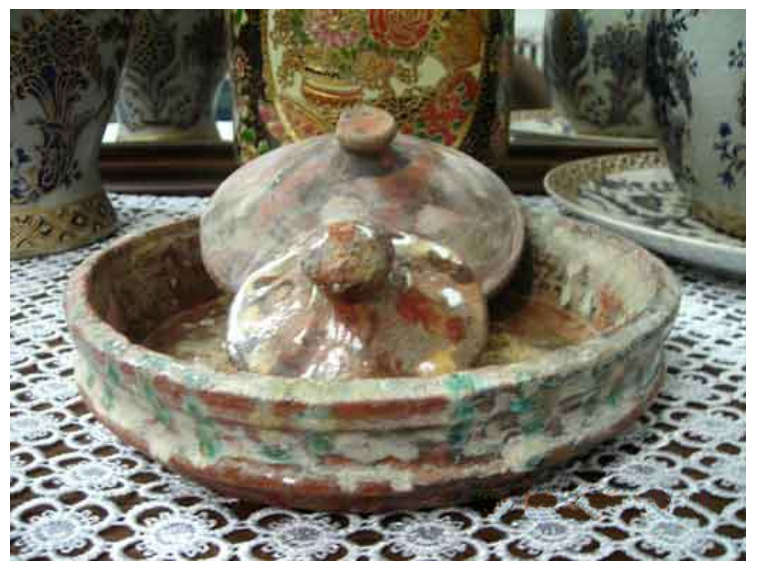

Görsel 24. Ünye'de üretilen sırlı formlar

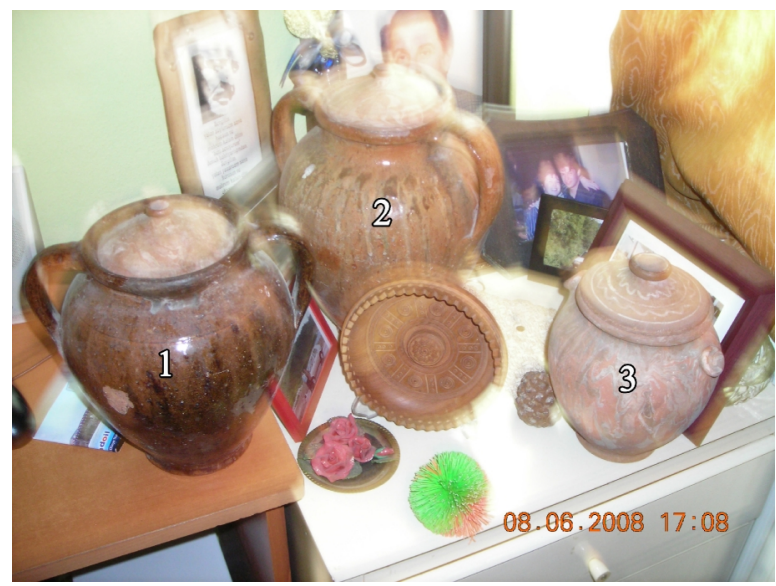

Görsel 25. Hüseyin Mistepe üretimi 1- Çökelek kab1, 2- Et kavurma ve tuzlu balık saklama kabı, 3- Tereyă̆ kab1 


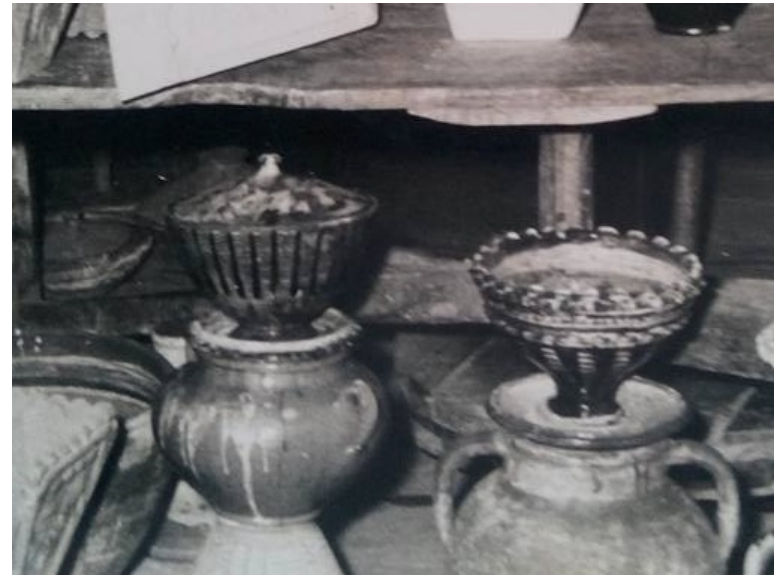

Görsel 26. Ünye'de üretilen sırlı formlar



Görsel 27. Hüseyin Mistepe'nin tasarladığı vazo, çaydanlık ve alçı kalıpları

\subsubsection{Kurutma}

Biçimlendirmesi tamamlanan formlar, kurutulmak için güneş ve rüzgar almayan depo denilen kurutma odalarında bekletilir. Havanın durumuna göre yirmi gün ile bir ay arasında kuruyan çömlekler pişirim işlemi için firına taşınır.

\subsubsection{Pişirim}

Salih Usta, firın yapımında kullanılan taşları, "erimeyen taşlardan seçilirdi” şeklinde anlatmıștır. Çömlek pişiriminde kullanılan firına "kara firın" denilir. Fırın tabanı, Borçka'nın geleneksel kara firını gibi çökmelere karşı bombelidir. Salih Usta'nın günümüzde kullandığı firının tabanı ise düzdür. Ünye'de geçmişte kullanılan firınlar yuvarlak planlıdır ve çap 1 3-5 metre arasında değişmektedir. Tepesi açık, yanlarında ise geniş bir kapı ve iki ya da üç pencere bulunur. Ürünler firına belli bir yüksekliğe kadar kapıdan, sonrasında ise üstten yüklenir. En büyük boy küpler ise kapının kenarındaki tuğlalar sökülerek yüklenir ve sonra tekrar örülerek (Görsel 28), çamurla sivanır.

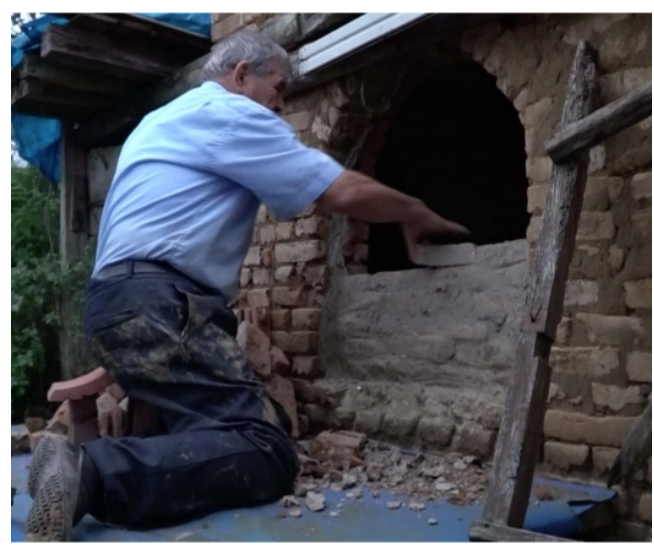

Görsel 28. Firına ürünler yüklendikten sonra kapısı tuğla ile örülür 
Kurutulan çömlekler pişirim işlemi için 8 ya da 10 kadın işçi tarafından firına yerleştirilir. Ürünler belli bir yüksekliğe kadar firının yan pencereden doldurulur, daha sonra da üstten doldurulmaya devam edilir. Büyük küpler en alta dizildikten sonra araları küçük testi ya da güveçlerle doldurulur. Fırın tamamen doldurulduktan sonra yanlardaki pencereler tuğla ile örülür ve çamurla sıvanır. Bu pencerelerde yanmayı kolaylaştırmak için çok küçük aralıklar bırakılır. Fırın tepeleme doldurulduktan sonra üstü kiremit ve çömlek parçaları ile kapatılır, açık kalan aralıklar hava almaması için çamurla sıvanır. Hazır olan fırın, ateşliğine atılan ince ağaç parçaları ve dallarla 1sıtılmaya başlanır ve 3-5 gün arası süreyle firın sıcaklığı kontrollü bir şekilde yükseltilir. Pişirimde gürgen ve meşe gibi ağaç türleri kullanılır. Pişirimin son gününde ateşin harlanması anlamına gelen ve "fayrap" denilen aşamaya geçilir ve fırının en üstündeki ürünler kor haline gelene kadar 12 saat daha yakılır. Pişirim bitirildikten sonra firın soğumaya bırakılır. Ürünlerin firından boşaltılması ve sevkiyata hazırlanması yine kadın işçiler tarafından yapılır [Y. Ellibeş (kişisel iletişim, Kasım 2019); A. Ellibeş (kişisel iletişim, Kasım 2019); M. U. Mistepe (kişisel iletişim, Kasım 2019)].

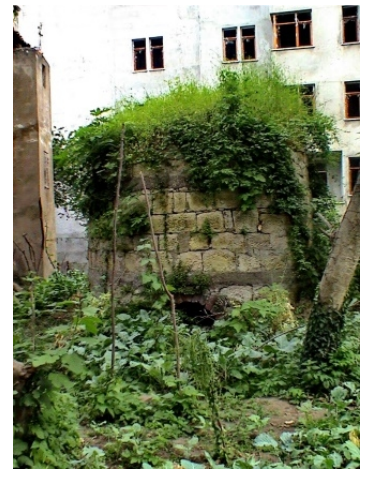

Görsel 29. İlyasoğlu Ahmet Yildız'ın kullandığ1 çömlekçi firını



a

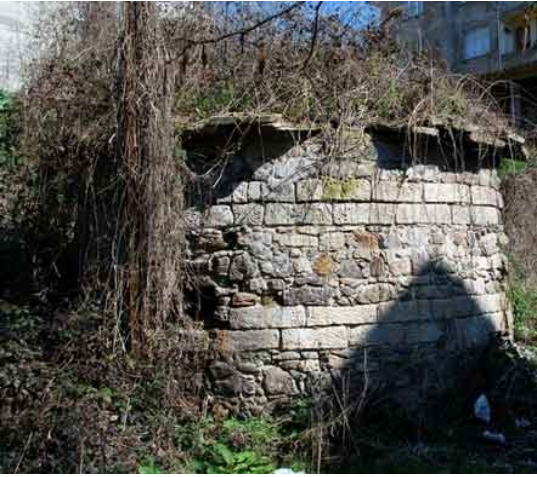

Görsel 30. Adil Usta'nın kullandığg çömlekçi fırını

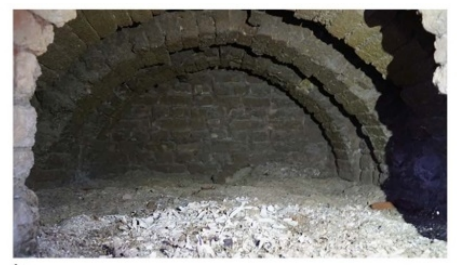

b



Görsel 31. a- Salih Usta’nın inşa ettiği kara firın, b- Ateşlik bölümü, c- Fırın tabanı (Öztürk, 2019)

\subsubsection{Sirlama}

Geçmişte yörede sülyen, soda ve boraks kullanılarak sırlama işlemi yapılmıştır. Renklendirici olarak ise bakır oksit kullanılmıştır. Sırlama işlemi, bisküvisi yapılmış çömleğin üzerine damlatılarak; ya da sır içine daldırılarak yapılmıştır. Damlatma, manda boynuzu içine doldurulan çeşitli oksit boya ya da sırın çarkta dönen çömleğin üzerine serpilmesi ile gerçekleştirilmiştir. Borçka'ya dönen Yusuf Ellibeş, sırlama işlemini burada yaptıklarını ancak olumlu sonuçlar alınamadığından devam ettirmedikleri bilgisini vermiştir.

Salih Karayiğit’in vermiş olduğu sır harmanı şu şekildedir;

$1 \mathrm{~kg}$ Boraks

$1 \mathrm{~kg}$ Sülyen

250 gr Soda

300 gr Buğday unu 
300 gr soda suda eritilir, içene boraks, sülyen, buğday unu eklenir ve karıştırılır. Buğday unu günümüzde sırların içine konulan seliloz yenine kullanılmıştır. İyice karıştırıldıktan sonra formlar sırlanır. Sırlama aşamasında sülyen dibe çökmesin diye iki-üç form sırlandıktan sonra karıştırılır. Sırlanan çömlekler, 24 saat süren ikinci bir pişirim yaplmıştır. Artan sır sonraki ürünlerde kullanılmak üzere saklanır.

\subsubsection{Sevkiyat}

Hazır hale gelen ürünler açıkta bekleyen motorlara yüklenerek Sinop-Ayancık gibi civar illere ve ilçelere sevk edilir. 1950'li yıllarda Devlet Su İşleri'nin siparişi üzerine Giresun ili için uzunca bir süre temiz su borusu imalatı yapılmıştır. 1950 ve sonrası ürün sevkiyatı, deniz yolu yanı sıra karayolu ile yapılmıştır.

\section{Sonuc}

1924 sonrası Ünye çömlekçiliği araştırıldığında, Burunucu Mahallesi’nden mübadele ile giden Rumlardan kalan çömlekçi atölyelerinin, yörenin ileri gelen tüccarlarından İlyasoğlu Ahmet Yıldız'ın girişimleri ile yeniden canlandırdığı bilgisine ulaşılmıştır. Araştırmada elde edilen diğer önemli bir bilgi de yeni ustaların yetiştirilmesi ve ocakların kurulmasında bilgi ve birikimi ile Borçkalı Şükrü Ellibeş Usta'nın önemli bir rol oynamış olmasıdır. Şükrü Usta Borçka'dan gelen kardeşi Hasan Usta ile uzunca bir süre yörede çömlek üretmiş ve yeni çıraklar yetiştirmiştir. 1952 yılında Borçka'ya ailesi ile birlikte geri dönen Hasan Usta, çömlekçiliği bırakmış ama oğlu Yusuf Usta çömlekçiliğe başlamıştır. Yusuf Usta, daha seri ve fazla sayıda ürün yapılabilmesi nedeniyle Ünye'de kullanılan çarkı kullanmaya başlamış ve Borçkalı ustalara da öğretmiştir. Ancak Borçka'da çömlek üretiminde kullanılan çamurun yapısının Ünye'de kullanılan çark tipine uygun olmadığı Borçka çömlekçiliğini araştırmak için yapılan saha çalışmasında öğrenilmiştir. Bu nedenle 1950 sonrası Borçka'da iki çark birden kullanılmıştır. 1927 sonrası Borçkalı ustaların Ünye çömlekçiliğini etkilediği gibi, Ünyeli ustalar da Borçka çömlekçiliğini etkilemiştir.

1927-1980’li yıllar arasında önemli bir çömlek üretim ve satış merkezi olan Ünye'de günümüzde çömlekçilik yapılmamaktadır. Salih Karayiğit isimli çömlekçi ise Sahilköy Mahallesi'ndeki atölyesinde tanıtım etkinlikleri yapmakta ve özel siparişler için çömlek üretmektedir. Günümüzde Ünye'de Salih Karayiğit dişında çömlek üretimi yapan yoktur. Eski çömlekçilerin birçoğu da hayatta değildir.

Ünye Çömlekçiliği hakkındaki bilgiler, Burunucu Mahallesi muhtarı Kemal Özdemir, Sahilköy Mahallesi muhtarı Mehmet Şensoy, Ünye tarihi hakkında araştırmalar yapan Ahmet Kabayel ve Ahmet Derya Varilci, Ufuk Mistepe, Ünye Belediyesi Projeler Sorumlusu Sibel Cerrahoğlu, Şükrü Ellibeş'in oğlu Aydın Ellibeş ve Hasan Ellibeş'in oğlu Yusuf Ellibeş ile yapılan görüşmeler sonucu alınmıştır. Nihat Mutlu ve Ömer Kaya'ya ait kaynak fotoğraflar, Kabayel ve Varilci vasitası ile elde edilmiştir.

Ünye Belediyesi'nden alınan bilgiye göre ilçede yapılacak "Kültür Yolu Projesi” kapsamında geleneksel çömlekçiliğin unutulmasını önlemek için çömlek atölyesi kurulması ve yeni ustaların yetiştirilmesi planlanmaktadır. Proje, DOKAP 5393 sayılı belediye kanunu madde 73, Kültür ve Tabiat Varlıklarını Koruma Kanunu ve 2634 sayılı Turizmi Teşvik Kanunu kapsamında, kültür ve turizm koruma ve gelişim bölgeleri ile turizm merkezlerinin belirlenmesine ve ilanına ilişkin yönetmelik doğrultusunda Ünye Belediyesi Kültür Yolu Proje ekibi tarafından hazırlanmıştır (www.unye.bel.tr, 2020). Burunucu mahallesi muhtarı Kemal Özdemir tarafindan kurulan atölyelerde yetiştirilen ustaların, hediyelik eşya üretmesi ve workshop yapması ile bu el sanatının canlanması ve unutulmamasının hedeflendiği belirtilmiştir. Projenin başarılı olması, belediyenin ve çalışan ustaların maddi kazanç elde etmesi ile bu el sanatının sürdürülebilirliği sağlanabilir. Ayrıca bu projenin hayata geçmesi, yörede kalan son ustanın bilgilerinden istifade etmek için önem arz etmektedir.

Türkiye'deki önemli çömlek üretim merkezlerinde yaşanan benzer sıkıntıları Ünye çömlekçiliği de yaşamıştır. Faal yapıldığı dönemde Ünye'de neredeyse çömlekçilikle uğraşmayan kimse kalmamışken, 1970'lerden günümüze, ucuz ve dayanıklı malzemelerin yaygınlaşması el emeğine dayalı üretilen malzemelerin gözden düşmesine sebep olmuştur. Diğer önemli çömlek üretim merkezleri gibi Ünye de bu durumla başa çıkamamış ve ekonomik getirilerin doğrultusunda varlığını devam ettirememiştir. Günümüzde birçok el sanatlarını tekrar canlandırmak ya da son bulmak üzere olanları desteklemek için çeşitli çalışmalar bulunmaktadır. Ancak her alanda olduğu gibi sürdürülebilirliği sağlamadan hatta garantilemeden hiçbir el sanatının devam etmesi mümkün görünmemektedir.

\section{Kaynakça}

Burunucu istimlak mahalli. (2019, 31 Mayıs). Erişim adresi: http://unyezile.com/burunucu.htm

Çağın gelişmişliğine direnen sanat. (2019, 31 Mayıs). Erişim adresi: http://unyezile.com/comlek.htm

Çanak çömlek kültürü. (2019, 31 Mayıs). Erişim adresi: http://unyezile.com/comlekci.htm

Güner, G. (1988). Anadolu'da yaşamakta olan ilkel çömlekçilik. İstanbul: Ak Yayınları 
İpek, N. (2000). Mübadele ve Samsun. Ankara: Türk Tarih Kurumu Basımevi

Öztürk, F. (2018). Borçka çömlekçiliği ve günümüzdeki durumu. Uluslararası Artvin Sempozyumunda sunulan bildiri, Artvin Çoruh Üniversitesi, Artvin.

Ünye Belediyesi. (2020). Kültür Yolu. Erişim adresi: https://www.unye.bel.tr/icerik.php?icerik=915\&Kategori $=1013$

\section{Görüsșeler}

Cerrahoğlu, S. (Nisan 2019). Ünye Belediyesi Projeler Müdürü Sibel Cerrahoğlu ile yapılan söyleşi, Ordu-Ünye

Ellibeş, A. (Kasım 2019). Şükrü Ellibeş’in oğlu Aydın Ellibeş ile yapılan yapılan, Ordu- Ünye

Ellibeş, S. (Kasım 2019). Şükrü Ellibeş'in akrabası Süheyla Ellibeş ile yapılan ksöyleşi, Artvin-Borçka

Ellibeş, Y. (Kasım 2019). Şükrü Ellibeş'in akrabası Yusuf Ellibeş ile yapılan söyleşi, Artvin-Borçka

Erdem, M. (Kasım 2019). Borçkalı Muhammet Erdem ile yapılan söyleşi, Artvin-Borçka

Kabayel, A. (Nisan-Kasım 2019). Tarih Araştırma Grubu üyesi Ahmet Kabayel ile yapılan söyleşi, Ordu-Ünye

Karayiğit, S. (Ekim 2019). Çömlek ustası Salih Karayiğit ile yapılan söyleşi, Ordu-Ünye, Sahilköy

Mistepe, M. U. (Kasım 2019). M.Ufuk Mistepe ile yapılan söyleşi, Ordu-Ünye

Özdemir, K. (Aralık 2019). Burunucu Mah. muhtarı Kemal Özdemir ile yapılan söyleşi, Ordu-Ünye

Şahin, Y. (Eylül-Ekim 2018- Eylül 2019). Çömlekçi Ustası Yüksel Şahin ile yapılan söyleşi, Artvin-Borçka

Şensoy, M. (Nisan-Aralık 2019). Sahilköy Mah. muhtarı Mehmet Şensoy ile yapılan söyleşi, Ordu-Ünye

Varilci, A. D. (Nisan-Kasım 2019). Tarih Araştırma Grubu Ahmet Derya Varilci ile yapılan söyleşi, Ordu-Ünye

\section{Görsel Kaynakçası}

Görsel 1. Burunucu Mahallesi. (2019). Kaynak: Ufuk Mistepe kişisel arşivi

Görsel 2. Burunucu mahallesi çömlekçi atölyeleri ve firınlar 1959 yılı öncesi. (2019). Kaynak: Ayşe Çağlar arşivi, http://www.unyezile.com

Görsel 3. Burunucu Sahili’nde 1950’li yıllarda çömlekçi çamuru hazırlama işlemi. (2019). Kaynak: Ufuk Mistepe kişisel arşivi

Görsel 4. Salih Usta-Çamur hazırlama, Salih Usta'nın atölyesi ziyareti. (2019). Kaynak: Filiz Öztürk kişisel arşivi

Görsel 5. 1950-1960 çamur hazırlama işlemi. (2019). Kaynak: Ufuk Mistepe kişisel arşivi

Görsel 6. Çamurun presten geçirilmesi. (2019). Kaynak: Ufuk Mistepe kişisel arşivi

Görsel 7. Salih Karayiğit atölyesindeki çamur ezme makinası. (2019). Filiz Öztürk kişisel arşivi

Görsel 8. Çömlek ustaları Abdullah Güney ve Faruk Yıldız. (2019). Ufuk Mistepe kişisel arşivi

Görsel 9. Borçka'da kullanılan çark. (2018). Kaynak: Esra Çora kişisel arşivi

Görsel 10. Ayakla döndürülen çark, Ünye. (2019). Kaynak: Filiz Öztürk kişisel arşivi

Görsel 11. Ünye'de kullanılan elektrikli çark ve seri üretimlerde kullanılan kapalı tezgah. (2019). Kaynak: Filiz Öztürk kişisel arşivi

Görsel 12. Biçimlendirmede kullanılan plastik ve metal aletler. (2019). Kaynak: Filiz Öztürk kişisel arşivi

Görsel 13. İlyasoğlu Ahmet Yıldız 1925-1935 Ünye'de üretilen formlar. (2019). Kaynak: Tarih Araștırma Grubu üyeleri Ahmet Derya Varilci ve Ahmet Kabayel arşivi

Görsel 14. 1972-1977 yılları arası Ünye'de üretilen formlar. (1988). Kaynak: Anadolu'da Yaşamakta Olan İlkel Çömlekçilik. s.91. İstanbul: Ak Yayınları.

Görsel 15. Ünye'nin çömlekçi ustaları. (2019). Kaynak: Ufuk Mistepe kişisel arşivi

Görsel 16. çömlekçi çırağının omuzundaki üçlü küp, sağdaki çömlekler hanıştıra su testisi. (2019). Kaynak: Ufuk Mistepe kişisel arşivi

Görsel 17. 1). Abdest testisi, 2). Birli küp, 3). Hanıştıra su testisi. (2020). Kaynak: Ufuk Mistepe kişisel arşivi 
Görsel 18. Yakın zamanda Ünye’de yapılan güveçler. (2020). Kaynak: Ufuk Mistepe kişisel arşivi

Görsel 19. Pöğrek (boru). (2020). Kaynak: Ufuk Mistepe kişisel arşivi

Görsel 20. İbrahim Adalı Usta, 1- Sürahi, 2- Künk, 3ve 4- Küçük-büyük baca havalandırma kapağı (nefeslik), 5Boru dirseği. (2020). Kaynak: Ufuk Mistepe kişisel arşivi

Görsel 21. Ünye'de üretilen sırlı formlar. (2019). Kaynak: Ufuk Mistepe kişisel arşivi

Görsel 22. Hüseyin Mistepe Usta'nın tasarladığı saksı. ( 2019). Kaynak: Ufuk Mistepe kişisel arşivi

Görsel 23. Hüseyin Mistepe ürettiği sırlı saksı. (2019). Kaynak: Ufuk Mistepe kişisel arşivi

Görsel 24. Ünye'de üretilen sırlı formlar. (2019). Kaynak: Ufuk Mistepe kişisel arşivi

Görsel 25. Hüseyin Mistepe üretimi. 1- Çökelek kabı, 2- Et kavurma ve tuzlu balık saklama kabı, 3- Tereyağı kab1 . (2019). Kaynak: Ufuk Mistepe kişisel arşivi

Görsel 26. Ünye'de üretilen sırlı formlar. (2019). Kaynak: Ufuk Mistepe kişisel arşivi

Görsel 27. Hüseyin Mistepe'nin tasarladığı vazo, çaydanlık ve alçı kalıpları. (2019). Kaynak: Ufuk Mistepe kişisel arşivi

Görsel 28. Fırına ürünler yüklendikten sonra kapısı tuğla ile örülür. (2019). Kaynak Filiz Öztürk kişisel arşivi

Görsel 29. İlyasoğlu Ahmet Yıldız'ın kullandığı çömlekçi firını. (2019). Kaynak: Tarih Araştıma Grubu üyeleri Ahmet Derya Varilci ve Ahmet Kabayel arşivi

Görsel 30. (Sağ) Adil Usta'nın kullandığı çömlekçi firını. (2019). Kaynak: Tarih Araştıma Grubu üyeleri Ahmet Derya Varilci ve Ahmet Kabayel arşivi

Görsel 31. a- Salih Usta'nın inşa ettiği kara firın, b- Ateşlik bölümü, c- Fırın tabanı. (2019). Kaynak: Filiz Öztürk kişisel arşivi 